\title{
PENGGUNAAN STUDY HISTORY SHEET (SHS) PADA MODEL DISCOVERY LEARNING TERHADAP HASIL BELAJAR SISWA
}

\author{
Sumari $^{1 *}$, Ridwan Joharmawan ${ }^{2}$, Aman Santoso $^{3}$, Dwi Ratna Wulandari ${ }^{4}$ \\ 1,2,3 Jurusan Kimia Fakultas Matematika dan Ilmu Pengetahuan Alam, Universitas Negeri Malang, \\ Jl Semarang No.5 Malang, Jawa Timur
}

\begin{abstract}
Abstrak - Tujuan penelitian ini adalah untuk mengetahui pengaruh penggunaan Study History Sheet (SHS) pada model discovery learning terhadap hasil belajar materi asam dan basa. Penelitian ini menggunakan rancangan quasi-eksperimental design jenis posttest only design. Kelas eksperimen dibelajarkan menggunakan model discovery learning dengan SHS, sedangkan kelas kontrol dibelajarkan menggunakan model discovery learning tanpa SHS. Hasil penelitian menunjukkan bahwa hasil belajar siswa yang proses pembelajarannya menggunakan model discovery learning dengan SHS lebih tinggi daripada yang proses pembelajarannya menggunakan model discovery learning tanpa SHS dengan nilai signifikansi sebesar 0,015 .
\end{abstract}

Kata kunci: discovery learning; study history sheet (SHS); hasil belajar; asam dan basa

\begin{abstract}
This study aimed to investigate the effect of using Study History Sheet (SHS) in the model of discovery learning towards students' achievement of acid and base topic. This study is a quasi-experimental design with posttest only. The results show that students' achievement of students who taught using discovery learning with SHS, is higher than the achievement of those who taught using discovery learning without SHS with the siginicant value of 0.015.
\end{abstract}

Keywords: discovery learning; study history sheet (SHS); students' achievement; acid and base

\section{PENDAHULUAN}

Salah satu mata pelajaran yang diajarkan di tingkat satuan Sekolah Menengah Atas (SMA) adalah kimia. Ilmu kimia mempelajari aspek makroskopis, submikroskopis, dan simbolik suatu materi. Aspek makroskopis dapat diindera, sedangkan aspek submikroskopis merupakan konsep abstrak. Dalam upaya memahami aspek makroskopis, peserta didik perlu melakukan pengamatan, sedangkan untuk konsep abstrak, peserta didik dituntut agar mampu memvisualisasikannya. Salah satu pokok bahasan dalam mata pelajaran kimia yang mencakup ketiga aspek tersebut adalah asam dan basa. Oleh karena itu, pembelajaran asam dan basa perlu melibatkan proses pengamatan atau pengalaman nyata, bukan hanya bersifat informatif.

Berdasarkan hasil wawancara terbuka dengan 10 peserta didik kelas XII di salah satu SMA, materi asam dan basa di sekolah umumnya diajarkan menggunakan metode ceramah. Metode ceramah bersifat informatif, yakni cara penyampaian bahan pelajaran yang menggunakan komunikasi lisan (Hasibuan dan Muedjiono, 2010:13). Menurut DePoter (2000), peserta didik memiliki gaya belajar yang berbeda-beda. Macam-macam gaya belajar peserta didik adalah visual (belajar dengan cara

\footnotetext{
* Corresponding authors: Jurusan Kimia, Universitas Negeri Malang, Malang 65145, Indonesia. Email: sumari.fmipa@um.ac.id
} 
melihat), auditori (belajar dengan cara mendengar), dan kinestetik (belajar dengan cara bergerak, bekerja, dan menyentuh).

Pokok bahasan asam dan basa merupakan pokok bahasan yang padat secara konseptual (Sheppard, 2006). Berdasarkan teori belajar bermakna Ausubel (Yamin, 2015), pengetahuan yang didapat dari proses hafalan mudah dilupakan peserta didik, sehingga pembelajaran menjadi tidak bermakna. Pembelajaran bermakna terjadi apabila peserta didik mengkonstruk pemahaman konsep dengan cara mengamati dan melakukan. Jika peserta didik mengalami pembelajaran bermakna, maka peserta didik akan memiliki pemahaman yang utuh, dan hasil belajar yang diperoleh akan baik (Lestari, 2013:133).

Salah satu model pembelajaran yang dapat mengkonstruk pemahaman peserta didik, sehingga peserta didik mampu mendapatkan pemahaman yang utuh adalah discovery learning. Menurut Bruner (dalam Hilmina, 2011), Discovery learning is a process in which student use information supplied to them to construct their own understanding. Artinya, peserta didik menggunakan informasi yang ada untuk membangun pemahamannya. Sejalan dengan Bruner, Mayer (dalam Sulistyowati, 2012) menjelaskan bahwa discovery learning merupakan salah satu model pembelajaran yang bertujuan melatih peserta didik untuk menemukan konsep secara mandiri. Penelitian yang dilakukan oleh Hilmina (2011) menunjukkan bahwa pembelajaran materi koloid menggunakan model discovery learning dapat meningkatkan hasil belajar peserta didik. Penelitian yang dilakukan Istiana dkk. (2014) juga menunjukkan hasil serupa, yakni penggunaan model discovery learning dapat meningkatkan hasil belajar siswa pada materi larutan penyangga. Dengan demikian model discovery learning perlu untuk dicoba diterapkan pada materi kimia yang lain.

Tahap-tahap model discovery learning yang dilakukan dalam penelitian ini adalah stimulasi, pernyataan masalah, pengumpulan data, pengolahan data, pembuktian, dan penarikan kesimpulan. Bruner (dalam Mufarricha, 2009) menjelaskan bahwa pembelajaran menggunakan model discovery learning membutuhkan adanya pengulangan-pengulangan yang disebut sebagai kurikulum spiral. Konsep yang terbentuk pada pertemuan sebelumnya akan terintegrasi dengan konsep yang ada pada pertemuan-pertemuan selanjutnya. Untuk mengatasi masalah tersebut, maka perlu digunakan Study History Sheet (SHS) dalam proses pembelajaran. Berdasarkan penelitian yang dilakukan oleh Purmita (2016), penggunaan SHS pada proses pembelajaran dapat meningkatkan hasil belajar materi koloid dari peserta didik.

SHS adalah lembaran berisi kotak-kotak yang digunakan peserta didik untuk menuliskan pengetahuan awal, rangkuman, dan pengetahuan baru yang didapat dari LKPD/LKS di tiap pertemuan. Satu SHS digunakan untuk satu pokok bahasan. Sehingga, ketika peserta didik tengah mempelajari subpokok bahasan ke-2 dan seterusnya, peserta didik dapat melihat lagi konsepkonsep yang ada pada subpokok bahasan sebelumnya yang telah ditulis pada kotak rangkuman. Hal tersebut diharapkan dapat mendukung keterlaksanaan model discovery learning yang menggunakan kurikulum spiral.

\section{METODE}

Rancangan penelitian ini adalah quasi-eksperimental design. Untuk mengungkapkan pengaruh pemberian perlakuan melibatkan kelas eksperimen dan kelas kontrol. Kelas eksperimen dibelajarkan menggunakan model discovery learning dan SHS, sedangkan kelas kontrol dibelajarkan menggunakan model discovery learning tanpa SHS.

Populasi penelitian ini adalah seluruh peserta didik kelas XI IPA SMA Batu yang terdiri dari 5 kelas. Teknik pengambilan sampel ini menggunakan teknik sampel acak berkelompok (cluster random sampling), satu sebagai kelas eksperimen dan satu sebagai kelas kontrol. 
Instrumen yang digunakan dalam penelitian ini berupa soal tes materi asam dan basa. Instrumen tes divalidasi isi oleh dosen dan guru serta divalidasi empirik oleh peserta didik. Instrumen tes yang sudah valid digunakan untuk mengambil data hasil belajar. Data dianalisis menggunakan analisis deskriptif dan statistik. Analisis statistik digunakan rumus independent sampel t-test dengan taraf sig. sebesar 0,05 dengan bantuan program SPSS for windows.

\section{HASIL DAN PEMBAHASAN}

\section{Kemampuan awal peserta didik}

Data kemampuan awal peserta didik diperoleh dari nilai ulangan harian kesetimbangan kimia yang merupakan pengetahuan prasyarat dari pokok bahasan asam dan basa. Data kemampuan awal peserta didik kelas eksperimen dan kelas kontrol digunakan untuk membandingkan kemampuan awal yang dimiliki oleh peserta didik kelas eksperimen dan kelas kontrol. Data kemampuan awal peserta didik dianalisis melalui uji kesamaan dua rata-rata. Hasil dari uji kesamaan dua rata-rata menunjukkan bahwa kemampuan awal yang dimiliki oleh peserta didik kelas eksperimen dan kelas kontrol adalah sama. Selain itu, kedua kelas sampel, juga dilakukan uji prasyarat analisis yaitu uji normalitas dan homogenitas. Ringkasan data kemampuan awal peserta didik kelas eksperimen dan kelas kontrol dapat dilihat pada Tabel 1.

Tabel 1. Ringkasan data kemampuan awal peserta didik kelas eksperimen dan kelas kontrol

\begin{tabular}{lcc}
\hline \multicolumn{1}{c}{ Deskripsi } & Kelas Eksperimen & Kelas Kontrol \\
\hline Jumlah peserta didik & 33 & 31 \\
Nilai tertinggi & 90,0 & 87,5 \\
Nilai terendah & 60,0 & 60,0 \\
Standar deviasi & 8,178 & 5,930 \\
Rata-rata nilai & 73,2 & 75,8 \\
\hline
\end{tabular}

Ringkasan hasil uji normalitas, homogenitas, dan kesamaan dua rata-rata kemampuan awal peserta didik kelas eksperimen dan kelas kontrol dapat dilihat pada Tabel 2, 3, dan 4 .

Tabel 2. Ringkasan hasil uji normalitas kemampuan awal peserta didik kelas eksperimen dan kelas kontrol

\begin{tabular}{lcccc}
\multirow{2}{*}{ Kelas } & \multirow{2}{*}{ Nilai Rata-rata } & \multicolumn{2}{c}{ Uji Kolmogorov-Smirnov } & \multirow{2}{*}{ Kesimpulan } \\
\cline { 3 - 4 } & & Standar Deviasi & Sig. & \\
\hline Eksperimen & 73,2 & 8,178 & 0,791 & Normal \\
Kontrol & 75,8 & 5,930 & 0,627 & Normal \\
\hline
\end{tabular}

Tabel 3. Ringkasan hasil uji homogenitas kemampuan awal peserta didik kelas eksperimen dan kelas kontrol

\begin{tabular}{llll}
\hline Kelas & Rata-rata Nilai & Sig. & Kesimpulan \\
\hline Eksperimen & 73,2 & 0,117 & \multirow{2}{*}{ Homogen } \\
Kontrol & 75,8 & & \\
\hline
\end{tabular}

Tabel 4. Ringkasan hasil uji kesamaan dua rata-rata kemampuan awal peserta didik kelas eksperimen dan kelas kontrol

\begin{tabular}{lccc}
\multicolumn{1}{c}{ Kelas } & Rata-rata Nilai & Sig. & Kesimpulan \\
\hline $\begin{array}{l}\text { Eksperimen } \\
\text { Kontrol }\end{array}$ & 73,2 & 0,144 & $\begin{array}{c}\text { Tidak ada perbedaan } \\
\text { kemampuan awal peserta } \\
\text { didik }\end{array}$ \\
\hline
\end{tabular}


Tabel 2 menunjukkan hasil uji normalitas kemampuan awal peserta didik kelas eksperimen dan kelas kontrol memiliki nilai sig. > 0,05, yaitu 0,791 dan 0,627. Sehingga dapat disimpulkan bahwa kemampuan awal peserta didik kelas eksperimen dan kelas kontrol terdistribusi normal. Tabel 3 menunjukkan hasil uji homogenitas kemampuan awal peserta didik kelas eksperimen dan kelas kontrol memiliki nilai sig. $>0,05$, yaitu 0,117. Sehingga dapat disimpulkan bahwa kemampuan awal peserta didik kelas eksperimen dan kelas kontrol memiliki varian yang sama. Tabel 4 menunjukkan hasil uji kesamaan dua rata-rata kemampuan awal peserta didik kelas eksperimen dan kelas kontrol memiliki nilai sig. > 0,05, yaitu 0,144. Dengan demikian dapat disimpulkan bahwa kemampuan awal peserta didik kelas eksperimen dan kelas kontrol adalah sama.

\section{Hasil Belajar Peserta Didik}

Data hasil belajar peserta didik didapat dari nilai skor tes pokok bahasan asam dan basa. Skor tes pokok bahasan asam dan basa terdiri dari 25 soal pilihan ganda. Data hasil belajar peserta didik kelas eksperimen dan kelas kontrol digunakan untuk membandingkan hasil belajar peserta didik kelas eksperimen setelah diberikan perlakuan dan kelas kontrol. Perlakuan yang dimaksud dalam penelitian ini adalah penggunaan SHS pada model pembelajaran Discovery Learning. Sebelum dilakukan uji hipotesis terlebih dahulu dilakukan uji prasyarat analisis yaitu uji normalitas dan homogenitas. Ringkasan hasil uji normalitas dan homogenitas hasil belajar peserta didik kelas eksperimen dan kelas kontrol dapat dilihat pada Tabel 5 dan 6.

Tabel 5. Ringkasan hasil uji normalitas hasil belajar peserta didik kelas eksperimen dan kelas kontrol

\begin{tabular}{lcccc}
\hline \multirow{2}{*}{ Kelas } & \multirow{2}{*}{ Rata-rata Nilai } & \multicolumn{2}{c}{ Uji Kolmogorov-Smirnov } & \multirow{2}{*}{ Kesimpulan } \\
\cline { 3 - 4 } & & Standar Deviasi & Sig. & \\
\hline Eksperimen & 82,79 & 8,030 & 0,163 & Normal \\
Kontrol & 78,19 & 6,600 & 0,276 & Normal \\
\hline
\end{tabular}

Tabel 6. Ringkasan hasil uji homogenitas hasil belajar peserta didik kelas eksperimen dan kelas kontrol

\begin{tabular}{lccc}
\multicolumn{1}{c}{ Kelas } & Rata-rata Nilai & Sig. & Kesimpulan \\
\hline Eksperimen & 82,79 & \multirow{2}{*}{0,169} & Homogen \\
Kontrol & 78,19 & & \\
\hline
\end{tabular}

Ringkasan data hasil belajar peserta didik kelas eksperimen dan kelas kontrol dapat dilihat pada Tabel 7 dan ringkasan hasil uji hipotesis hasil belajar peserta didik dapat dilihat pada Tabel 8 .

$\underline{\text { Tabel 7. Ringkasan data hasil belajar peserta didik kelas eksperimen dan kelas kontrol }}$

\begin{tabular}{lcc}
\multicolumn{1}{c}{ Deskripsi } & Kelas Eksperimen & Kelas Kontrol \\
\hline Jumlah peserta didik & 33 & 31 \\
Nilai tertinggi & 96 & 92 \\
Nilai terendah & 72 & 68 \\
Standar deviasi & 8,030 & 6,600 \\
Rata-rata nilai & 82,79 & 78,19 \\
\hline
\end{tabular}

Tabel 8. Ringkasan hasil uji hipotesis hasil belajar peserta didik kelas eksperimen dan kelas kontrol

\begin{tabular}{lccc}
\multicolumn{1}{c}{ Kelas } & Nilai Rata-rata & Sig. & Kesimpulan \\
\hline Eksperimen & 82,79 & \multirow{2}{*}{0,015} & $\begin{array}{l}\text { Ada perbedaan hasil } \\
\text { belajar peserta didik }\end{array}$ \\
Kontrol & 78,19 & & bela \\
\hline
\end{tabular}

Tabel 5 menunjukkan hasil uji normalitas hasil belajar peserta didik kelas eksperimen dan kelas kontrol memiliki nilai sig. $>0,05$, yaitu 0,163 dan 0,276. Sehingga dapat disimpulkan bahwa hasil belajar peserta didik kelas eksperimen dan kelas kontrol terdistribusi normal. Tabel 6 menunjukkan hasil uji homogenitas hasil belajar peserta didik kelas eksperimen dan kelas kontrol memiliki nilai 
sig. $>0,05$, yaitu 0,169. Sehingga dapat disimpulkan bahwa hasil belajar peserta didik kelas eksperimen dan kelas kontrol memiliki varian yang sama.

Setelah didapatkan hasil uji normalitas dan homogenitas hasil belajar peserta didik kelas eksperimen dan kelas kontrol dilakukan uji hipotesis. Uji hipotesis dilakukan menggunakan rumus independent sample t-test dan dianalisis dengan bantuan program SPSS for windows. Hipotesis penelitian yang diajukan adalah sebagai berikut.

$\mathrm{H}_{1}$ : Hasil belajar pokok bahasan asam dan basa yang diperoleh peserta didik kelas XI SMA di kelas yang menggunakan model discovery learning dan SHS lebih tinggi daripada di kelas yang menggunakan model discovery learning tanpa SHS.

Hasil uji hipotesis hasil belajar peserta didik kelas eksperimen dan kelas kontrol yang terdapat pada Tabel 8 memiliki nilai sig. $<0,025$, yaitu 0,015. Rata-rata hasil belajar peserta didik kelas eksperimen sebesar 82,79, lebih tinggi dari rata-rata hasil belajar peserta didik kelas kontrol yang hanya sebesar 78,19. Dengan demikian, dapat disimpulkan bahwa hasil belajar pada pokok bahasan asam dan basa yang diperoleh peserta didik kelas XI SMA Batu di kelas yang menggunakan model discovery learning dan SHS lebih tinggi daripada di kelas yang menggunakan model discovery learning tanpa SHS (terima $\mathrm{H}_{1}$ ). Hubungan penggunaan SHS terhadap hasil belajar peserta didik dapat dilihat pada Gambar 1 dan 2.

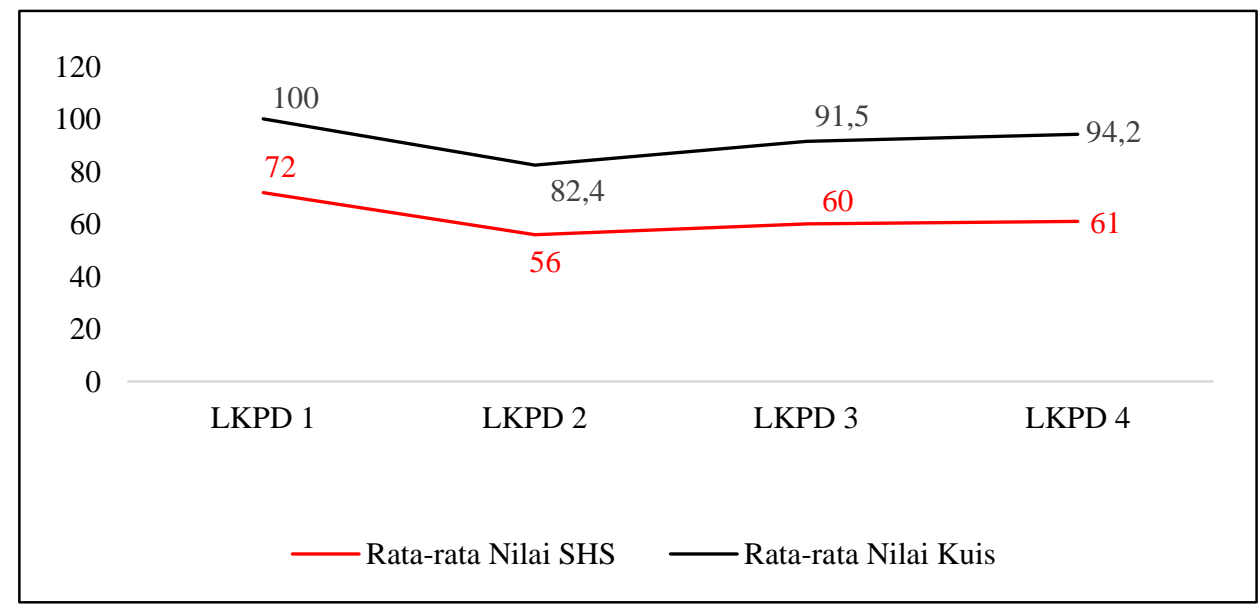

Gambar 1. Grafik hubungan antara rata-rata nilai $S H S$ dan kuis peserta didik

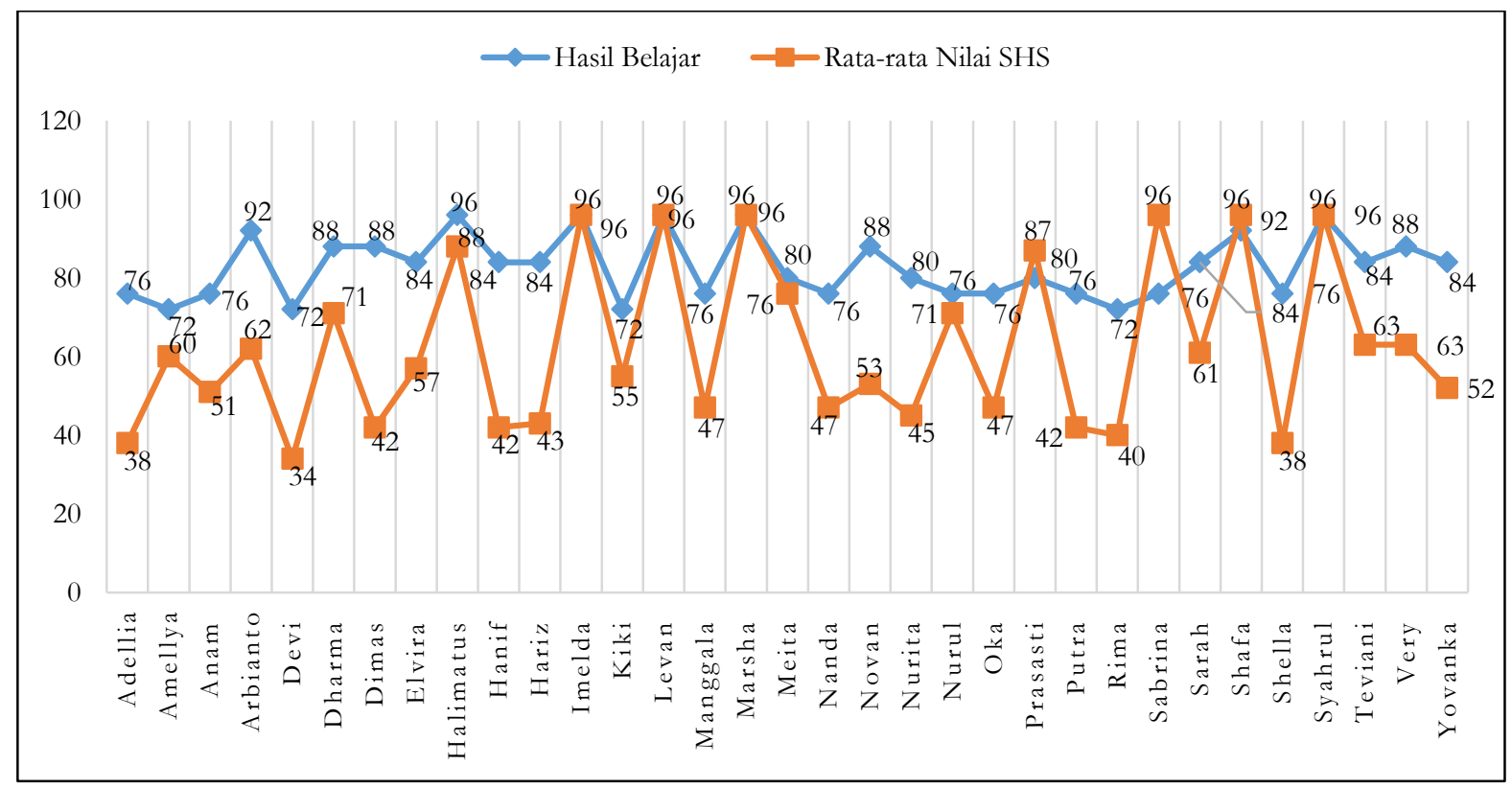

Gambar 2. Grafik hubungan antara rata-rata nilai $S H S$ dan hasil belajar peserta didik 
Gambar 1 menunjukkan kesetaraan antara rata-rata nilai $S H S$ dengan kuis peserta didik pada tiap LKPD. Berdasarkan grafik tersebut, terlihat bahwa rata-rata nilai $S H S$ peserta didik pada tiap LKPD berbanding lurus dengan rata-rata nilai kuisnya. Semakin tinggi rata-rata nilai SHS peserta didik pada tiap LKPD, maka semakin tinggi pula rata-rata nilai kuisnya.

Gambar 2 menunjukkan hubungan antara rata-rata nilai SHS dengan hasil belajar peserta didik. Berdasarkan grafik tersebut, dapat diketahui hubungan korelasi antara rata-rata nilai SHS dengan hasil belajar peserta didik. Hubungan korelasi antara kedua data dicari menggunakan rumus product moment dengan bantuan microsoft office excel. Koefisien korelasi ( $\mathrm{r}$ ) yang didapatkan sebesar 0,64, dengan kriteria hubungan korelasi kuat dan diperoleh $\mathrm{r}^{2}$ sebesar 0,41 yang berarti SHS memiliki sumbangan efektif sebesar $41 \%$ terhadap hasil belajar. Sehingga, dapat disimpulkan bahwa semakin tinggi rata-rata nilai $S H S$ peserta didik, maka semakin tinggi pula hasil belajarnya. Dengan demikian, dapat dikatakan bahwa penggunaan SHS pada model discovery learning dapat meningkatkan hasil belajar peserta didik.

SHS terdiri dari tiga bagian, yaitu kotak sebelum belajar, rangkuman, dan setelah belajar. Satu SHS digunakan untuk satu pokok bahasan. Sehingga, ketika peserta didik tengah mempelajari subpokok bahasan ke-2 dan seterusnya, peserta didik dapat melihat lagi konsep-konsep yang ada pada subpokok bahasan sebelumnya yang telah ditulis pada kotak rangkuman. Hal tersebut dapat memudahkan peserta didik untuk belajar. Konsep-konsep yang ada pada subpokok bahasan sebelumnya dapat dijadikan referensi oleh peserta didik guna menemukan konsep baru pada pokok bahasan selanjutnya. Sedangkan kotak sebelum dan setelah belajar akan membuat peserta didik mengetahui perubahan pengetahuan yang dimilikinya. Hal tersebut sesuai dengan penjelasan Shizuo, et al. (2011:68) bahwa penggunaan SHS dalam pembelajaran dapat membantu peserta didik mengetahui kegiatan sebelumnya dan perubahan pengetahuan yang dimilikinya, sehingga muncul kepuasan terhadap diri masing-masing peserta didik akibat adanya perubahan pengetahuan yang dimiliki setelah proses pembelajaran.

Adanya proses koreksi dan pembenaran terhadap SHS peserta didik dapat mengurangi kemungkinan terjadinya kesalahan konsep atau kesalahan pemahaman. Hasil temuan konsep selama proses pembelajaran yang dituliskan peserta didik di SHS akan dikoreksi oleh guru. Jika peserta didik menuliskan suatu pemahaman atau konsep yang salah, maka guru akan menuliskan konsep yang benar pada SHS tersebut. Menurut Yamin (2015), proses koreksi dan pembenaran akan menyebabkan peserta didik mengetahui kesalahannya. Kesalahan yang dibuat peserta didik dimaknai sebagai bagian dari cara belajar membangun pemahaman-pemahaman baru yang lebih baru, serta menjadikan diri lebih kritis. Jadi, ketika peserta didik melihat hasil koreksi terhadap SHSnya dan mengetahui bahwa ada yang salah dengan pemahamannya, maka peserta didik sebisa mungkin akan menghindari adanya kesalahan yang baru dan menjadi lebih teliti.

Berdasarkan ulasan-ulasan tersebut, maka dapat disimpulkan bahwa penggunaan SHS pada model discovery learning adalah dapat memudahkan peserta didik untuk belajar, memberikan kepuasan tersendiri terhadap perubahan pengetahuan yang dimiliki peserta didik sebelum dan sesudah pembelajaran, menghindari terjadinya kesalahan konsep atau kesalahan pemahaman yang diterima oleh peserta didik, dan melatih peserta didik untuk menjadi lebih kritis.

\section{KESIMPULAN}

Penggunaan model discovery learning dan SHS lebih efektif daripada model discovery learning tanpa $S H S$ pada pembelajaran materi asam basa. Terdapat korelasi positif antara skor rerata SHS dengan skor tes peserta didik pada tiap LKPD. Semakin tinggi skor rerata SHS peserta didik pada tiap LKPD, semakin tinggi pula skor rerata tes yang diperolehnya. 


\section{DAFTAR RUJUKAN}

DePorter, B., Reardon, M. \& Nourie, S.S. (2000). Quantum Teaching: Mempraktikkan Quantum Learning di Ruang-ruang Kelas. Bandung: Mizan Media Utama.

Hasibuan, J. J. \& Mudjiono. (2010). Proses Belajar Mengajar. Bandung: PT Remaja Rosdakarya.

Hidefumi, A., Shizuo, M., Shousuke, T., Taro, Hatogai., Tetsuto, H. \& Yukio, S. (2011). Development and Practice of "Air Polution" Educational Unit Aiming an Education for Sustainable Development. Educational Workshop Report. 64-71.

Hilmina. (2011). Upaya Meningkeatkan Hasil Belajar Kimia Siswa dengan Metode Discovery Melalui Kegiatan Laboratorium pada Konsep Sistem Koloid. Skripsi tidak diterbitkan. Jakarta: UIN Syarif Hidayatullah.

Istiana, G.A., S Catur, A.G. \& Sukardjo, J.S. (2015). Penerapan Model Discovery learning untuk Meningkatkan Aktivitas dan Prestasi Belajar Pokok Bahasan Larutan Penyangga pada Siswa Kelas XI IPA Semester II SMA Negeri 1 Ngemplak Tahun Pelajaran 2013/2014. Jurnal Pendidikan Kimia, 4 (2): 65-73.

Lestari, D. (2013). Penerapan Teori Bruner untuk Meningkatkan Hasil Belajar Siswa pada Pembelajaran Simetri Lipat di Kelas IV SDN 02 Makmur Jaya Kabupaten Mamuju Utara. Jurnal Kreatif Tadulako, 3 (2): 129-144.

Mufarricha, L. (2009). Konsep Pembelajaran Menurut Jerome S Bruner dalam Perspektif Pembelajaran Pendidikan Agama Islam Karya Mubaimin. Skripsi tidak diterbitkan. Surabaya: Institut Agama Islam Negeri Sunan Ampel.

Purmita, D. (2016). Pengaruh Penggunaan Lembar Study History Sheet (SHS)-Model Pembelajaran Learning Cycle 3 Fase Terhadap Hasil Belajar Siswa Kelas XI IPA SMA Negeri 7 Malang pada Materi Koloid. Skripsi tidak diterbitkan. Malang: Universitas Negeri Malang.

Sanjaya, W. (2007). Strategi Pembelajaran. Jakarta: Kencana.

Sheppard, K. (2006). High School Students "Understanding of Titrations and Related Acid-Base Phenomena". Chemistry Education Research and Practice, 7 (1): 32-45.

Sulistyowati, N., Sumarni, W. \& Widodo, A. T. (2012). Efektivitas model pembelajaran guided discovery learning terhadap kemampuan pemecahan masalah kimia. Jurnal Chemistry in Education, 2 (1):50.

Syah, M. 2005. Psikologi Pendidikan dengan Pendekatan Baru. Bandung: Remaja Rosdakarya.

Widayati, A. 2004. Metode mengajar sebagai strategi dalam mencapai tujuan belajar mengajar. Jurnal Pendidikan Akuntansi Indonesia, 3 (1): 68.

Yamin, M. 2015. Teori dan Metode Pembelajaran: Konsepsi, Strategi dan Praktik Belajar yang Membangun Karakter. Malang: Madani. 